\title{
Warehouse Location selection for an electricity distribution company by KEMIRA-M method
}

\author{
Bir elektrik dağıtım firması için KEMIRA-M yöntemi ile depo yeri seçimi
}

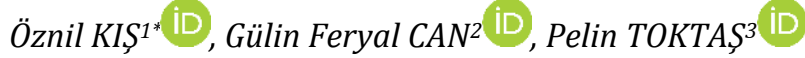 \\ 1,2,3Industrial Engineering Department, Engineering Faculty, Başkent University, Ankara, Turkey. \\ oznilkis@gmail.com,gfcan@baskent.edu.tr, ptoktas@baskent.edu.tr
}

Received/Geliş Tarihi: 03.02.2019, Accepted/Kabul Tarihi: 09.05.2019

* Corresponding author/Yazışılan Yazar

doi: $10.5505 /$ pajes.2019.98354

Research Article/Araștırma Makalesi

\begin{abstract}
In this study, by using Modified Kemeny Median Indicator Ranks Accordance (KEMIRA-M) approach which begins to become popular in recent times for solution of Multi criteria Decision Making (MCDM) problems, warehouse location selection for an electricity distribution company is performed. KEMIRA-M logically distinguishes criteria into two groups and it computes criteria importance weights by including interactions between both groups. KEMIRA-M considers both decision makers' preferences related to the priorities of criteria and quantitative or qualitative values of these criteria in decision making process. Decision makers can change importance weights of criteria based on median priority component representing expected rankings of criteria importance weights and they can see the effect of this variability on rankings of alternatives. In warehouse location selection problem investigated in this study, it is aimed to choose the favorable location considering different criteria and these criteria were grouped firm related and environmental criteria to evaluate 20 alternative warehouse locations. In this context, as firm related criteria; Operation Center-Meeting Point (OC-MP) transportation cost per month, main warehouses' transportation costs per month, number of connected OC$M P$, consumption amounts of OC-MP were considered. Population, distance to the closest main road, average distance to main supplier, mobility, investment amounts in 2018, average delivery time and land cost were taken into account as environmental criteria group.
\end{abstract}

Keywords: KEMIRA, Warehouse, Location selection, Electricity distribution, MCDM

\section{Introduction}

Effective supply chain management is needed for companies to meet continuously changing requirements in the marketplace. By reducing supply chain risk and uncertainty, companies can enhance customer service, optimize inventory levels, improve business processes and reduce cycle times, resulting in increased competitiveness and profitability. Warehouse location selection is one of the most critical decisions in supply chain design and management.

In today's competitive market environment, companies are continuously forced to improve their warehousing operations [1]. Many companies have also customized their value proposition to increase their customer service levels, which has led to changes in the role of warehouses [1]. Warehousing also affects the total logistics costs of a company, as reducing warehousing costs can lead to an increase in transportation costs [2]. Choosing the right location for a warehouse can prevent an increase of the total logistics costs and its positive effects may only become apparent over time [2].
Öz

Bu çalıșmada, Cok Kriterli Karar Verme (CKKV) problemlerinin çözümü için son zamanlarda popüler hale gelen Modifiye Edilmiş Kemeny Medyan Gösterge Siralaması Uygunluk Yaklașımı (Modified KEmeny Median Indicator Ranks Accordance, KEMIRA-M) kullanilarak; bir elektrik dağıtım șirketi için depo yeri seçimi gerçekleștirilmiștir. KEMIRA-M, kriterleri mantıksal olarak iki gruba ayırmakta ve her iki grup arasındaki etkileșimleri de kapsayarak kriter önem ağırlıklarını hesaplamaktadır. KEMIRA-M, karar vericilerin hem kriter öncelikleriyle ilgili tercihlerini hem de kriterlerin nicel veya nitel değerlerini dikkate almaktadır. Karar vericiler, kriterlerin önem ağırlıklarını medyan bileșen öncelikleri temelinde değiștirebilirler ve bu değişkenliğin etkilerini alternatiflerin sıralaması üzerinde görebilirler. Bu çalısmada incelenen depo yeri seçim probleminde farklı kriterler göz önünde bulundurularak en uygun yerin seçilmesi amaçlanmıștır. Bu kriterler 20 depo yeri alternatifinin değerlendirilmesi için çevresel ve firma ile ilişkili kriterler olmak üzere iki gruba ayrılmıștır. Bu kapsamda, firma iliskili kriterler olarak; Operasyon Merkezi-Bulușma Noktası Depolarının (OC-MP) aylık ulaşım maliyetleri, 2018 yatırım tutarları, aylık ana depolar arası ulașım maliyetleri, bağlı OC-MP sayısı ve OC-MP tüketim tutarları dikkate alınmıștır. Çevresel kriterler olarak; nüfus, en yakın ana yola uzaklık, ana tedarikçiye ortalama uzaklık, hareket esnekliği, ortalama teslimat süresi ve arazi maliyeti göz önünde bulundurulmuştur.

Anahtar kelimeler: KEMIRA, Depo, Yer seçimi, Elektrik dağıtımı, CKKV

Suitable warehouse location selection is also very significance part of the logistics systems for an Electricity Distribution Company, because energy is indispensable for a city. Electrical materials which maintain the electricity grid of the city are stored at these warehouses. Warehouse location is a long-term decision and is influenced by many quantitative and qualitative factors [3]. Hence, warehouse location selection is a MultiCriteria Decision Making (MCDM) problem. MCDM is an approach to rank and select the best from a set of feasible alternatives.

Among supply chain studies, many papers on location selection problem have been published. The existing literature does not indicate a systematic fashion of location selection research. However, the study of location selection has a long and extensive history spanning many general research fields including operations research (or management science), industrial engineering, geography, economics, computer science, mathematics, marketing, electrical engineering, urban planning [4]. Brief information for warehouse location selection studies is given below. 
Han et al. [5] studied the supply location selection and routing (SLSR) problem via considering uncertain demand and formulating as a probabilistic constrained integer programming (PCIP) model. Cao et al. [6] analyzed the inevitable trend of cooperation between estate logistic, logistic enterprise, manufacturing firm and retail. They constructed the simulated annealing (SA) model with the comprehensive consideration of estate logistics firm and customers' profit. Liang and $\mathrm{Tu}$ [7] investigated how to select the warehouse location for time limited aeronautical emergency material. A warehouse location selection model for aeronautical emergency material has been established based on the setcovering theory. Feng et al. [8] used index system for location evaluation of logistics center constructed by analyzing influencing factors of logistics center location. Then, the fuzzymatter element model based on Grey Relation Analysis (GRA) was built in view of the fuzziness and incompatibility of evaluation index in evaluation of logistics center location and the model was used to choose the best scheme. Demirel and Kahraman [3] applied multi-criteria Choquet integral to a real warehouse location selection problem of a big Turkish logistic firm. Özcan et al. [9] compared the results of Analytic Hierarchy Process (AHP), Technique for Order Preference by Similarity to Ideal Solution (TOPSIS), Elimination and Choice Expressing Reality (ELECTRE) and GRA for the warehouse selection problem, which is one of the main topics of logistics management in retail sector. Natarajan et al. [10] implemented TOPSIS, Elemination and Choice Translating Reality English (ELECTRE) and GRA for warehouse selection for mobile phone industry in special economic zone. Public Bonded warehouse was found as a best warehouse among the alternatives and comparative analysis were done by using $\mathrm{C}++$ programming software. Uysal and Tosun [11] considered labor, transportation, environment and geographical location as decision criteria and used GRA under the sustainability basis for the warehouse location selection problem. This method is appropriate for solving the group decision-making problem in an uncertain and inconsistent environment. Warehouse location alternatives for the supply chain of the medical companies are evaluated in this study. Aktepe and Ersöz [12] solved warehouse site selection problem by using three different methods as AHP, Vise Kriterijumska Optimizacija I Kompromisno Resenje (VIKOR) and Multi-Objective Optimization by Ratio Analysis (MOORA). AHP method was used for determining the importance weights of criteria. VIKOR and MOORA methods were used for ranking alternatives. Erbaş et al. [13] performed spatial analysis of the Geographical Information Systems (GIS) for warehouse location selection for hazardous materials. Jayant [14] selected the most appropriate warehouse location for a manufacturing organization. Here, three MCDM techniques VIKOR, TOPSIS, GRA were used to facilitate decision making in the selection of a warehouse. The model proposed in this paper determines the most appropriate warehouse location alternative through maximization of objectives. A case study of manufacturing company was presented to illustrate these three MCDM techniques for the selection of warehouse facility. Malmir et al. [15] proposed a new balancing and ranking method combined with an interval data approach for solving a warehouse location selection problem. This method involves a three-step procedure to derive an overall complete final order of the warehouses which are already selected for the decision making. Dey et al. [16] proposed three new extended fuzzy MCDM methodologies capable of handling subjective and objective factors for the evaluation and selection of warehouse location. The concept of fuzzy set theory was integrated with the TOPSIS, Simple Additive Weight (SAW) and MOORA to assess subjective criteria in terms of subjective factor measures. Mangalan, et al. [17] calculated the personal preference for criteria using Simos' procedure (1990) for the ware house location. Then, MOORA used to optimize the rankings of warehouse sites. Zhu et al. [18] used probabilistic model checking to provide a formal way to select the best express delivery storage locations. Probabilistic Computation Tree Logic (PCTL) was employed to specify the requirements of delivery system. The Probabilistic Symbolic Model Checker (PRISM) was used to the qualitative verification and probabilistic simulation of each step in delivery fetches process. Devangan [19] developed an integrated production and distribution planning (IPDP) optimization model for a multi-product, multi-plant, multi-location and multi-echelon supply chain environment with multiple transport options including railways and roads. Özbek and Erol [20] developed a model to select the best place for storage. The study utilized AHP, SAW, Complex Proportional Assessment (COPRAS) and MOORA to form an integrated model. Cömert and Yener [21] determined an optimal warehouse location of a food company using the Fuzzy AHP. Sezer et al. [22] proposed a multiple criteria decision problem for hazardous material warehouse selection. In particularly, for the explosives storage among other hazardous materials, necessary criteria are determined according to expert's consultant. The determined criteria are weighted according to DMs' consultancies and the alternatives were evaluated by fuzzy Multi-Objective Optimization by Ratio Analysis (MULTIMOORA) under uncertainty. Dey et al. [23] proposed a new Multi criteria Group Decision Making (GDM) approach in adroit exploitation of the group heterogeneity during evaluation process and restrict the biasness of information while decision making. To overcome the biasness, the consistency check mechanism of AHP was employed. He et. al [24] identified key effectiveness-oriented criteria used to evaluate the alternative emergency warehouse locations and made an attempt to propose a new multi criteria ranking method to solve the problem of inaccurate or uncertain weight information based on stochastic pairwise dominant relations and the pruning procedure of ELECTRE-II method. Gül and Eren [25] developed a multi criteria optimization approach by combining AHP and goal programming (GP) model for warehouse location selection process in a public sector. Shukla et al. [26] solved location selection problem for a modern agriwarehouse using Fuzzy AHP. Büyüközkan and Uztürk [27] proposed group decision-making (GDM) technique based on 2tuple linguistic model, quality function deployment (QFD) and the TOPSIS method. This proposed framework was then applied to a green warehouse selection problem. Chen et. al [28] provided a data-smart approach for addressing the connected capacitated warehouse location problem (CCWL), which searches for the minimum total transportation cost of the warehouse network including supplier-warehouses shipping cost, warehouse customer delivering cost and the cost of warehouse-warehouse inter-transportation. Izdebski et al. [29] developed the genetic algorithm in order to solve the multi-criteria warehouse location problem in the logistics network. Jha et al. [30] identified and modeled critical success factors (CSFs) for the selection of sustainable warehouse for Indian chemical industries. Through literature survey and experts' opinions, 14 critical factors were identified, and the interpretive structural modeling (ISM) approach was used to establish interrelationship among the defined parameters and 
to determine the key criteria having high driving power. Lin and Wanga [31] resolved the problems of deciding the optimal warehouse location for multiple markets and determining warehouse configuration design against stochastic demands. An appropriate inventory policy with owned and rented warehouses for deteriorating items was further designed. Brunaud et al. [32] proposed a Mixed-integer Linear Programming model to determine the optimal number location and capacity of the warehouses required to support a long-term forecast with seasonal demand. Kabak and Keskin [33] determined the most suitable location for an explosive and ammunition warehouse to be established in the Marmara Region of Turkey, with an aim to minimize the transportation costs from the point of origin (warehouse) to the distribution point and simultaneously minimize or eliminate impact to the environment and living beings. A hybrid methodology of a mathematical model, AHP and GIS are proposed for the solution of this problem. Foroozesh et al. [34] selected the most optimal location from a number of potential sustainable warehouse candidates and presented a novel MCDM model by a group of supply chain experts with interval-valued fuzzy setting and asymmetric uncertainty information. Emeç [35] developed a stochastic MCDM approach to solve the warehouse location problem in the stochastic environment which contains uncertain condition. Singha et al. [36] found the most optimal location for a warehouse in Special Economic Zones (SEZs) and Free Trade Zones (FTZs) of Iran on the basis of different criteria derived from literature. Guo et al. [37] applied a Monte Carlo simulation to simulate future well locations, Then they selected several suitable candidates using a continuous location model and finally they used discrete location optimization to determine the optimal solution while also considering the distribution interruption problem. In the context of literature review study, 97 numbers of studies in between 2009-2018 focusing on location selection problem are analyzed. There are 38 studies are related about warehouse selection problem. The distribution of these studies including warehouse location selection by years is given in Figure 1.

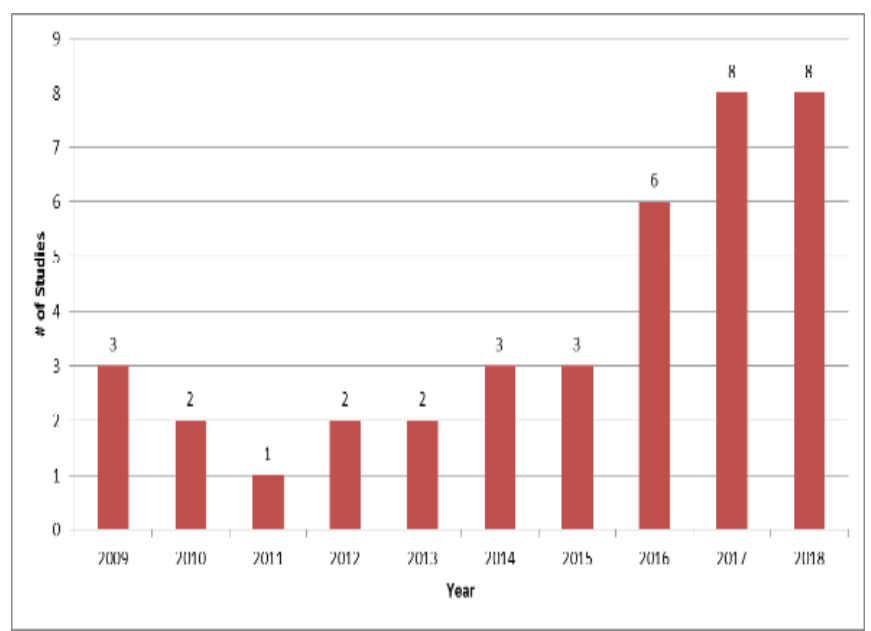

Figure 1: Distribution of warehouse location selection problems between 2009-2018.

In Figure 2, distribution of sectors where warehouse location selection is performed can also be seen.



Figure 2: Distribution of sectors.

Figure 3 shows the methodologies used for location selection in these 38 studies.



Figure 3: Methodologies used in studies.

As seen from the literature, ware house location selection is the popular topic for researchers. However, KEMIRA-M has not been used for this problem. Therefore, it is a hot topic to use KEMIRA-M to determine the most suitable warehouse location alternative. In this study, the most suitable location is aimed to determine for an electrical material warehouse to be established for the Electricity Distribution Company domain. 
Warehouse location selection is an important decision that directly affects logistics management. One of the factors increasing or decreasing costs in logistics activities is the selection of warehouse locations. Today, a positive or negative competition environment depends on a good settlement decision. Competition shows itself through the prices determined as the basis for the cost expenses. A good placement makes creating a location that will provide an affordable cost and a bad settlement has reverse effect. The choice of warehouse location is a decision requiring a long-term strategic planning level that includes the size, geographical location and number of warehouses etc.. Because of considering many different criteria to evaluate different numbers of location multi criteria decision making (MCDM) approaches provide flexibility in decision process. Among MCDM approaches, KEMIRA-M which is a new generation and powerful methodology can model location selection decision in a detailed manner.

The decision process in KEMIRA-M is carried out considering both the decision makers' opinions and the qualitativequantitative values that the alternatives take for the criteria simultaneously. Additionally, KEMIRA-M is based on the fact that decision makers create a priority order instead of using a scale when determining criteria weight. Final criteria rankings are obtained via aggregating these different priorities of decision makers. The combined priority of the criteria is determined to be the least difference between the decision makers. According to this order, the decision makers have the flexibility to make different weightings with a total of 1 . In addition, the method can show changes in alternative rankings for different criteria weights given by decision makers in its inner procedure.

"KEMIRA-M uses two heuristics as prioritizing criteria groups separately and determining criteria weights according to the median priority components. In KEMIRA-M procedure, the differences between the priorities of decision makers in terms of criteria are considered and median priority component forms a decision rule for criteria weights' rankings. Decision makers have to assign criteria weights based on median priority component. This provides a systematic and flexible approach for determining criteria weights. Median priority component is the aggregation of different rankings of decision makers in terms of criteria. In location selection problem, different decision makers may have different priorities for different location alternatives. Additionally, KEMIRA-M can reflect qualitative and quantitative values of criteria and priorities of decision makers for criteria in solution process at the same time. The increase in the number of alternatives does not create any problems in the evaluation for KEMIRA-M. This also applies to cases where the number of criteria increases. Because KEMIRA-M separates criteria in to sub sets according to their structural similarities. KEMIRA-M categorizes criteria according to their features. In this way, criteria for querying similar information about alternatives can be gathered. This feature is very usable for location selection problem because location selection is a decision process including different criteria in different natures. Each criterion group allows decision makers to evaluate location alternatives from different perspectives." The combination of all these features shows the greatest differences between the KEMIRA-M method and the other MCDM approaches. The rest of the paper is organized as follows: In the second section, explanation of KEMIRA-M Method is given. In the third section, KEMIRA-M application for
Warehouse Location Selection is represented. The last section includes conclusions and discussions.

\section{Modified Kemeny median indicator ranks accordance (KEMIRA-M) method}

Modified Kemeny Median Indicator Ranks Accordance (KEMIRA-M) allows simultaneous identification of the criteria weights and accomplishes ranking procedure of alternatives [11]. This method is especially efficient when there are separate groups of criteria and the criteria weights must be computed for each group [11]

The decision process is carried out considering both the decision makers' opinions and the qualitative-quantitative values that the alternatives take according to the criteria simultaneously. Additionally, the method is based on the fact that decision makers create a priority order instead of using a scale when determining criteria weight. Final criteria rankings are obtained via aggregating these different priorities of DMs. The combined priority of the criteria is determined to be the least difference between the DMs. According to this order, the decision makers have the flexibility to make different weightings with a total of 1 . In addition, the method can show different alternative rankings in which different weights are reflected to DMs. The combination of all these features shows the greatest differences between the KEMIRA-M method and the other MCDM approaches.". Krylovas et al. [38] performed KEMIRA-M for solving specific task of elite selection from security personnel. Krylovas et. al [39] applied KEMIRA-M Method which is an extend version of KEMIRA for the case study of construction site selection for non-hazardous waste incineration plant. Toktaș and Can [40] used KEMIRA-M to rank risk levels of construction worksites in terms of work health and safety. They combined Quality Function Deployment with KEMIRA-M to obtain the ranks of risk criteria based on risk degrees of risk types. They considered two criteria groups as quantitative indicators and precaution indicators related to nine construction worksites. They modeled relations between risk types encountered in worksites and indicators. Delice and Arslan [41] performed KEMIRA-M to select the best drone among seven alternatives according to seven criteria as camera quality, control distance, flight time, weight, cost, aesthetic and usability. They grouped these criteria into two classes as internal criteria group and external criteria group. Toktaş and Can [42] used KEMIRA-M to select the best SM in Ankara, Turkey. They considered two criteria groups as technical and universal design. As seen from the KEMIRA-M literature, KEMIRA-M has been tried to combine different approaches like Entropy, QFD and it has also been used for different decision areas. This shows increasing attention for KEMIRA-M. Additionally, researchers are trying to implement KEMIRA-M for more than two dimensions. KEMIRA-M algorithm consists of the following steps:

Step 1. Determine the criteria, alternatives and form expert group.

Criteria are denoted as $x_{i} ; i=1, \ldots, m$ and $y_{j} ; j=1, \ldots, n . x_{i}$ and $y_{j}$ form two different criteria groups with different nature such as subjective and objective or internal and external. Alternatives are denoted as $A_{k} ; k=1, \ldots, K$. Experts are shown as $E_{s}, s=1, \ldots, S$.

Step 2. Categorize the criteria as cost and benefit type. 
All criteria in decision process in KEMIRA-M should be transformed into benefit type [43]. The benefit type criteria are always wanted to have higher values. If the value of the criterion for an alternative is higher, this means that the respective alternative has the better performance for this criterion than the other alternatives. If criterion $x_{i}$ is cost type criterion, the value of this criterion is transformed into the benefit type criterion by implementing $\frac{1}{x_{i}}$ [43]. This conversion is also applied for $y_{j}$.

Step 3. Form the initial decision matrix.

Initial decision matrix is indicated as $[D]$. The elements of $[D]$ consist of $x_{i}^{(k)}$ and $y_{j}^{(k)}$ as in Eq. (1).



where;

$x_{i}^{(k)}$ is the $i t h$ criterion value in the first criterion group for the $k$ th alternative.

$y_{j}^{(k)}$ is the $j$ th criterion value in the second criterion group for the $k t h$ alternative.

Step 4. Normalize initial decision matrix.

Criteria values in $[D]$ are normalized according to the Eq. (2).

$$
x_{i}^{(k) *}=\frac{x_{i}^{(k)}-x_{\min }^{(k)}}{x_{\max }^{(k)}-x_{\min }^{(k)}}, \quad y_{j}^{(k) *}=\frac{y_{j}^{(k)}-y_{\min }^{(k)}}{y_{\max }^{(k)}-y_{\min }^{(k)}}
$$

where;

$x_{i}^{(k) *}$ is the normalized value of $i t h$ criterion in the first criterion group for the $k t h$ alternative.

$y_{j}^{(k) *}$ is the normalized value of $j t h$ criterion in the second criterion group for the $k t h$ alternative.

$x_{\min }^{(k)}$ is the criterion value which is minimum in the first criterion group for all alternatives.

$y_{\min }^{(k)}$ is the criterion value which is minimum in the second criterion group for all alternatives.

$x_{\max }^{(k)}$ is the criterion value which is maximum in the first criterion group for all alternatives.

$y_{\max }^{(k)}$ is the criterion value which is maximum in the second criterion group for all alternatives.

Before normalization process, all cost type criteria should be turned into benefit type criteria as $1 / x_{i}^{(k)}$ and $1 / y_{j}^{(k)}$ respectively.

Step 5 . Determine the priority of criteria for each expert.

Each expert $\left(E_{S}, s=1, \ldots, S\right)$ prioritizes criteria in the first and second group independently and separately as in Table 1.

If a criterion in any of two groups is assigned a value as " 1 ", it means that it is the most important criterion among the others in the same group. The rank of ith criterion in the first group determined by sth expert is denoted as $\left(x_{i}\right)_{r}^{s}$ providing $\left(x_{i}\right)_{r}^{S} \in\{1,2, \ldots, m\}$. The rank of $j$ th criterion in the second group determined by sth expert is denoted as $\left(y_{j}\right)_{r}^{s}$ providing $\left(y_{j}\right)_{r}^{s} \in\{1,2, \ldots, n\}$.
Table 1: Priorities established by experts for the first and second group criteria.

\begin{tabular}{ccccccccccc}
\hline$E_{s}$ & $\boldsymbol{x}_{\mathbf{1}}$ & $\cdots$ & $\boldsymbol{x}_{\boldsymbol{i}}$ & $\cdots$ & $\boldsymbol{x}_{\boldsymbol{I}}$ & $\boldsymbol{y}_{\mathbf{1}}$ & $\cdots$ & $\boldsymbol{y}_{\boldsymbol{j}}$ & $\cdots$ & $\boldsymbol{y}_{\boldsymbol{J}}$ \\
\hline 1 & $\left(x_{1}\right)_{r}^{1}$ & $\cdots$ & $\left(x_{i}\right)_{r}^{1}$ & $\cdots$ & $\left(x_{I}\right)_{r}^{1}$ & $\left(y_{1}\right)_{r}^{1}$ & $\cdots$ & $\left(y_{j}\right)_{r}^{1}$ & $\cdots$ & $\left(y_{J}\right)_{r}^{1}$ \\
$\cdots$ & $\cdots$ & $\cdots$ & $\cdots$ & $\cdots$ & $\cdots$ & $\cdots$ & $\cdots$ & $\cdots$ & $\cdots$ & $\cdots$ \\
$s$ & $\left(x_{1}\right)_{r}^{s}$ & $\cdots$ & $\left(x_{i}\right)_{r}^{s}$ & $\cdots$ & $\left(x_{I}\right)_{r}^{s}$ & $\left(y_{1}\right)_{r}^{s}$ & $\cdots$ & $\left(y_{j}\right)_{r}^{s}$ & $\cdots$ & $\left(y_{J}\right)_{r}^{s}$ \\
$\cdots$ & $\cdots$ & $\cdots$ & $\cdots$ & $\cdots$ & $\cdots$ & $\cdots$ & $\cdots$ & $\cdots$ & $\cdots$ & $\cdots$ \\
$S$ & $\left(x_{1}\right)_{r}^{s}$ & $\cdots$ & $\left(x_{i}\right)_{r}^{s}$ & $\cdots$ & $\left(x_{I}\right)_{r}^{s}$ & $\left(y_{1}\right)_{r}^{s}$ & $\cdots$ & $\left(y_{j}\right)_{r}^{s}$ & $\cdots$ & $\left(y_{J}\right)_{r}^{s}$ \\
\hline
\end{tabular}

Step 6. Form the priority matrix for each expert for each criterion.

$x_{(i)}^{S}$ defines the ith importance order of $x_{i}$ for sth expert. For expert $s, x_{(1)}^{s}$ shows the most important criterion among $x_{i}, i=$ $1,2, \ldots, m$ and $x_{(m)}^{s}$ represents the least important criterion among $x_{i}, i=1,2, \ldots, m$. Then, $x_{(1)}^{s}>x_{(2)}^{s}>\cdots>x_{(i)}^{s}>\cdots>$ $x_{(m)}^{s}$ presents the priorities of $x_{i}$ (first criteria group) determined by sth expert.

The elements of priority matrix $\left[P_{X}^{S}\right]_{m \times m}$ for the first criteria group for each expert are denoted as $\left(p_{i t}\right)^{s}, i=1,2, \ldots, m, t=$ $1,2, \ldots, m$. $\left(p_{i t}\right)^{s}$ given in Eq.(3) defines the priority of ith criterion in the first group according to $t$ th criterion in the first group for sth expert.

$$
\left(p_{i t}\right)^{s}= \begin{cases}0, & \text { if } x_{(i)}^{s}<x_{(t)}^{s} \\ 1, & \text { if } x_{(i)}^{s}>x_{(t)}^{s}\end{cases}
$$

Similarly, the elements of priority matrix $\left[P_{Y}^{S}\right]_{n \times n}$ for the first criteria group for each decision maker are indicated as $\left(p_{j z}\right)^{s}, j=1,2, \ldots, n ; z=1,2, \ldots, n .\left(p_{j z}\right)^{s}$ given in Eq.(4) defines the priority of $j$ th criterion in the second criterion group according to $z$ th criterion in the second criterion group for $s t h$ expert.

$$
\left(p_{j z}\right)^{s}= \begin{cases}0, & \text { if } y_{(j)}^{s} \prec y_{(z)}^{s} \\ 1, & \text { if } y_{(j)}^{s}>y_{(z)}^{s}\end{cases}
$$

Step 7. Find the distance between each expert's priority.

Priority distance $\rho_{X}^{S}, l=1, \ldots, m$ for each expert for the first criterion group $X=\left\{x_{1}, x_{2}, \ldots, x_{i}, \ldots, x_{m}\right\}$ are computed as in Eq.(5).

$$
\begin{aligned}
\rho_{X}^{1} & =\sum_{s=1}^{S} \sum_{i=1}^{m} \sum_{t=1}^{m}\left|\left(p_{i t}\right)^{1}-\left(p_{i t}\right)^{s}\right| \\
\rho_{X}^{2} & =\sum_{s=1}^{S} \sum_{i=1}^{m} \sum_{t=1}^{m}\left|\left(p_{i t}\right)^{2}-\left(p_{i t}\right)^{s}\right| \vdots \\
\rho_{X}^{S} & =\sum_{s=1}^{S} \sum_{i=1}^{m} \sum_{t=1}^{m}\left|\left(p_{i t}\right)^{S}-\left(p_{i t}\right)^{s}\right|
\end{aligned}
$$

Then, the minimum value of $\rho_{X}^{S}, s=1,2, \ldots, S$ is obtained as in Eq. (6).

$$
\rho_{X}=\min \left\{\rho_{X}^{1}, \rho_{X}^{2}, \ldots, \rho_{X}^{S}\right\}
$$


$x_{(1)}^{S}$ is the most important among $x_{i}, i=1, \ldots, m$ and $x_{(I)}^{S}$ is the least important among $x_{i}, i=1,2, \ldots, m$ for expert $s t h . s^{*}$ is an expert whose priority ranking providing $\rho_{X}$ is defined as $x_{(1)}^{s^{*}}>$ $x_{(2)}^{s^{*}}>\cdots>x_{(I)}^{s^{*}}$. Then, this priority ranking is named as priority median components for the first criterion group. In the same manner, priority distance $\rho_{Y}^{S}, j=1, \ldots, n$ for each expert for the second criterion group $Y=\left\{y_{1}, y_{2}, \ldots, y_{j}, \ldots, y_{n}\right\}$ is computed as in Eq.(7).

$$
\begin{gathered}
\rho_{Y}^{1}=\sum_{s=1}^{S} \sum_{z=1}^{n} \sum_{j=1}^{n}\left|\left(p_{j z}\right)^{1}-\left(p_{j z}\right)^{s}\right| \\
\rho_{Y}^{2}=\sum_{l=1}^{S} \sum_{z=1}^{n} \sum_{j=1}^{n}\left|\left(p_{j z}\right)^{2}-\left(p_{j z}\right)^{s}\right| \\
\rho_{Y}^{L}=\sum_{s=1}^{S} \sum_{z=1}^{n} \sum_{j=1}^{n}\left|\left(p_{j z}\right)^{S}-\left(p_{j z}\right)^{S}\right|:
\end{gathered}
$$

Then, the minimum value of $\rho_{Y}^{S}, l=1,2, \ldots, S$ is computed as in Eq.(8).

$$
\rho_{Y}=\min \left\{\rho_{Y}^{1}, \rho_{Y}^{2}, \ldots, \rho_{Y}^{L}\right\}
$$

$y_{(1)}^{S}$ is the most important among $y_{j}, j=1,2, \ldots, n$ and $y_{(J)}^{S}$ is the least important among $y_{j}, j=1,2, \ldots, n$ for expert sth. $s^{*}$ is an expert whose priority ranking providing $\rho_{Y}$ is defined as $y_{(1)}^{s^{*}}>$ $y_{(2)}^{s^{*}}>\cdots>y_{(J)}^{s^{*}}$. Then, this priority ranking is named as priority median components for the second criterion group.

Step 8. Assign criteria weights according to the median priority components.

Each expert determines criteria weights according to the median priority components for each criterion group. The conditions for weights are given below:

$w_{x_{1}}+w_{x_{2}}+w_{x_{3+}} \ldots+w_{x_{n}}=1, w_{y_{1}}+w_{y_{2}}+w_{y_{3}+\cdots}+w_{y_{4}}=1$.

Step 9. Form the weighted normalized vector of alternatives for each weight set.

The decision on alternatives' rankings is made according to the values of sums of linear combinations $v_{x}+v_{Y}$, calculated for each alternative [43]. $v_{x}$ is the weighted normalized vector of alternatives for the first group criteria. It is obtained via multiplying $w_{X}$ with the first group criteria part of $[D]$ as in Eq.(9). The element of $v_{x}$ is represented as $v_{X}^{(k)} ; k=1,2, \ldots, K$.

$$
v_{x}=\left[\begin{array}{c}
v_{X}^{(1)} \\
v_{X}^{(2)} \\
\vdots \\
v_{X}^{(K)}
\end{array}\right]=\left[\begin{array}{l}
\sum_{i=1}^{m}\left(x_{i}^{(1)}\right)^{\prime} \cdot w_{x_{i}} \\
\sum_{i=1}^{m}\left(x_{i}^{(2)}\right)^{\prime} \cdot w_{x_{i}} \\
\vdots \\
\sum_{i=1}^{m}\left(x_{i}^{(K)}\right)^{\prime} \cdot w_{x_{i}}
\end{array}\right]
$$

Weighted normalized vector of alternatives for the second criterion group $v_{Y}$ is obtained by multiplying $w_{Y}$ with second criteria group part of $[D]$ as in Eq.(10). The element of $v_{Y}$ is represented as $v_{Y}^{(k)}, k=1,2, \ldots, K$.

$$
v_{Y}=\left[\begin{array}{c}
v_{Y}^{(1)} \\
v_{Y}^{(2)} \\
\vdots \\
v_{Y}^{(K)}
\end{array}\right]=\left[\begin{array}{c}
\sum_{j=1}^{n}\left(y_{j}^{(1)}\right)^{\prime} \cdot w_{y_{j}} \\
\sum_{j=1}^{n}\left(y_{j}^{(2)}\right)^{\prime} \cdot w_{j} \\
\vdots \\
\sum_{j=1}^{n}\left(y_{j}^{(K)}\right)^{\prime} \cdot w_{y_{j}}
\end{array}\right]
$$

Step 10. Rank the alternatives.

To rank alternatives Eq.(11) and Eq.(12) are implemented.

$$
\begin{gathered}
F_{(X, Y)}=\sum_{k=1}^{K}\left|v_{X}^{(K)}-v_{Y}^{(K)}\right| \\
F_{\left(X^{*}, Y^{*}\right)}=\min F_{(X, Y)}
\end{gathered}
$$

Weights satisfying Eq.(12) denoted as $w_{x}^{*}=\left(w_{x_{1}}^{*}, \ldots, w_{\chi_{m}}^{*}\right)$ for the first criterion group and $w_{y}^{*}=\left(w_{y_{1}}^{*}, \ldots, w_{y_{n}}^{*}\right)$ for the second criterion group are used to rank the alternatives. To find the final ranks of the alternatives Eq.(13) is used.

$$
S=v_{X}+v_{Y}
$$

where $v_{X}$ and $v_{Y}$ are calculated as in Eq. (9) and Eq. (10) using $w_{x}^{*}$ and $w_{y}^{*}$. The elements of $S$ denoted as $s^{(k)}$ are the sum of the weighted normalized values of alternatives $s^{(k)}=v_{X}{ }^{(k)}+$ $v_{Y}{ }^{(k)}, k=1,2, \ldots, K$. The highest value of $s^{(k)}$ shows the best alternative.

\section{KEMIRA-M application for warehouse location selection}

This study focuses on warehouse location selection problem for an electricity distribution company by using KEMIRA-M. Company where the application was performed has three main warehouses for continuing their logistics activity as seen in Figure 4 . They want to open more than one main warehouse to increase customer satisfaction and decrease delivery time and transportation costs. Therefore, they determined 20 alternative warehouse locations for this aim. The 20 possible alternative locations for a new warehouse are presented in Table 2. The implementation steps of KEMIRA-M given in Section 2 were utilized for this problem as below.

Step 1. Determine the criteria, alternatives and form expert group.

To select the best warehouse location, two criteria groups were determined as firm related criterion group and environmental criterion group. Firm related criterion group consists of five criteria as the number of connected OC-MP $\left(x_{1}\right)$, consumption amounts of OC-MP $\left(x_{2}\right)$, investment amounts for $2018\left(x_{3}\right)$, OCMP transportation cost per month $\left(x_{4}\right)$, main warehouses' transportation cost per month $\left(x_{5}\right)$. Environmental criterion group includes six different criteria as population $\left(y_{1}\right)$, distance to the closest main road $\left(y_{2}\right)$, average distance to main supplier $\left(y_{3}\right)$, mobility $\left(y_{4}\right)$, average delivery time $\left(y_{5}\right)$ and land cost $\left(y_{6}\right)$. Among these criteria, mobility is evaluated in a qualitative manner by using 1-5 scale changing between "least mobile and most mobile". 20 numbers of alternative warehouse locations $A_{k} ; k=1, \ldots, 20$ were evaluated according to these criteria. Opinions of five experts $E_{s}, s=1, \ldots, 5$ are considered for the evaluation. Two warehouse specialists, one planning and 
logistics team leader, one strategic supply chain team leader and one supply chain manager whose experiences in this sector are average 5-10 years evaluated the priorities of criteria.

Step 2. Categorize the criteria as cost and benefit type.

Number of connected OC-MP $\left(x_{1}\right)$, consumption amounts of OCMP $\left(x_{2}\right)$, investment amounts of $2018\left(x_{3}\right)$, population $\left(y_{1}\right)$ and mobility $\left(y_{4}\right)$ are benefit type criteria and OC-MP transportation cost per month $\left(x_{4}\right)$, main warehouses' transportation costs per month $\left(x_{5}\right)$, distance to the closest main road $\left(y_{2}\right)$, average distance to main supplier $\left(y_{3}\right)$, average delivery time $\left(y_{5}\right)$, land cost $\left(y_{6}\right)$ are cost type criteria.
Initial decision matrix $[D]$ is shown in Table 3.

Step 4. Normalize initial decision matrix.

Criteria values in $[D]$ are normalized by using Eq.(2) as seen in Table 4.

Step 5. Determine the priority of criteria for each expert.

Priority rankings for the firm related criteria group and environmental criteria group for each expert are given in Table 5. As seen from Table 6, according to the first expert, first criterion in the firm related criteria group is the most important, fifth criterion in the same group is the least important.

Step 3. Form the initial decision matrix.

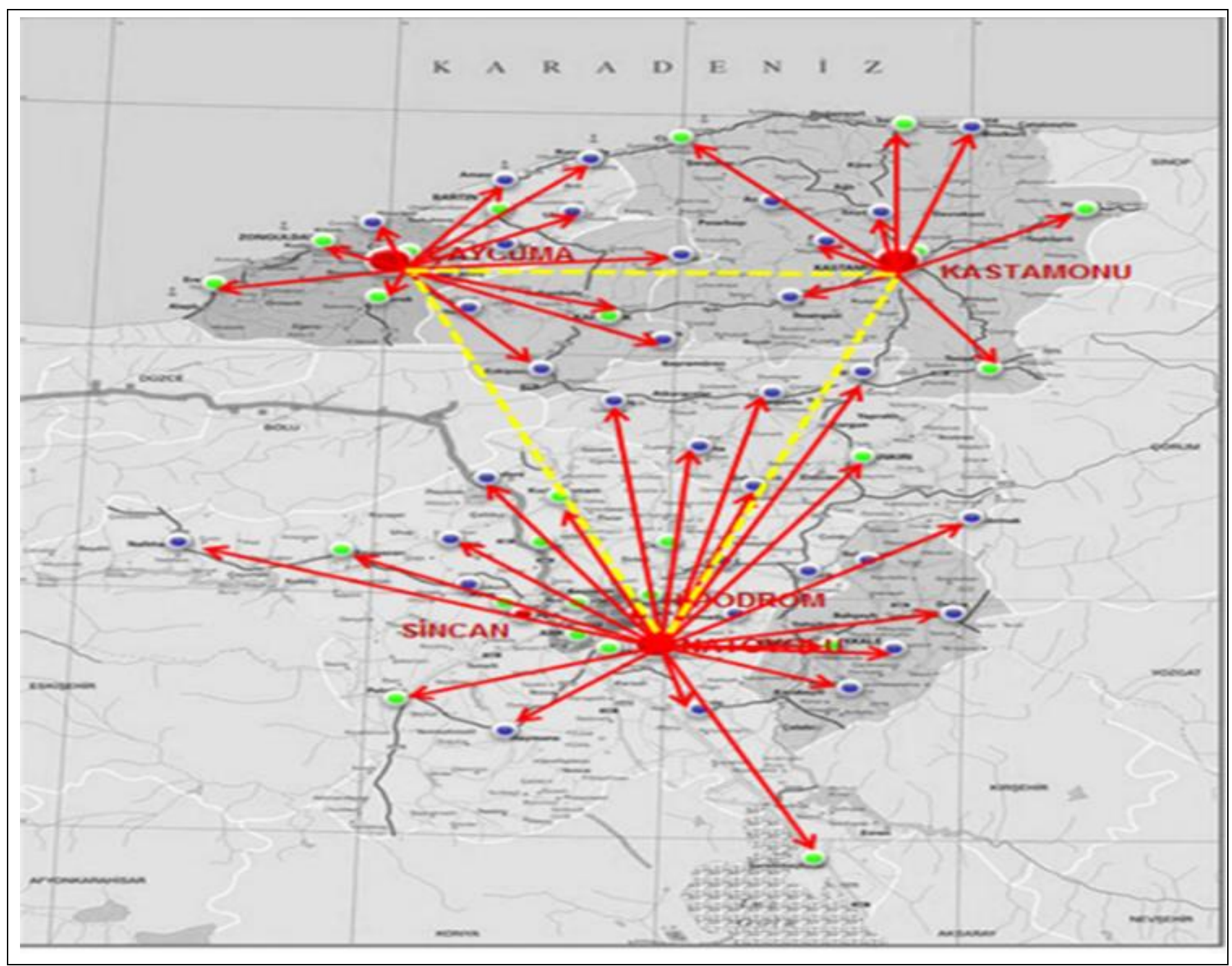

Figure 4: Present logistic network.

Table 2: 20 location alternatives for new warehouse.

\begin{tabular}{|c|c|c|c|c|c|c|c|c|c|c|}
\hline $\begin{aligned} & A_{i} \\
& i=1, \ldots, 20\end{aligned}$ & $A_{1}$ & $A_{2}$ & $A_{3}$ & $A_{4}$ & $A_{5}$ & $A_{6}$ & $A_{7}$ & $A_{8}$ & $A_{9}$ & $A_{10}$ \\
\hline Location & Taşköprü & Tosya & Cide & İnebolu & Çankırı & Zonguldak & Ereğli & Devrek & Karabük & Bartın \\
\hline $\begin{aligned} & A_{i} \\
& i=1, \ldots, 20\end{aligned}$ & $A_{11}$ & $A_{12}$ & $A_{13}$ & $A_{14}$ & $A_{15}$ & $A_{16}$ & $A_{17}$ & $A_{18}$ & $A_{19}$ & $A_{20}$ \\
\hline Location & Çankaya & Beypazarı & Sincan & Kızılcahamam & Kazan & Kırıkkale & Polatll & Şereflikoçhisar & Çubuk & Gölbaşı \\
\hline
\end{tabular}


Table 3: Initial decision matrix.

\begin{tabular}{|c|c|c|c|c|c|c|c|c|c|c|c|}
\hline \multirow{2}{*}{$A_{k}$} & \multicolumn{5}{|c|}{ Firm related criteria group } & \multicolumn{6}{|c|}{ Environmental criteria group } \\
\hline & $x_{1}$ & $x_{2}$ & $x_{3}$ & $x_{4}$ & $x_{5}$ & $y_{1}$ & $y_{2}$ & $y_{3}$ & $y_{4}$ & $y_{5}$ & $y_{6}$ \\
\hline$A_{1}$ & 1 & 2 & 55 & 24 & 600 & 38171 & 5 & 465 & 5 & 5 & 66 \\
\hline$A_{2}$ & 4 & 13 & 66 & 2330 & 618 & 40280 & 2 & 389 & 5 & 43 & 48 \\
\hline$A_{3}$ & 5 & 4 & 108 & 1524 & 677 & 22212 & 4 & 484 & 2 & 43 & 110 \\
\hline$A_{4}$ & 4 & 6 & 83 & 1943 & 738 & 21716 & 4 & 524 & 4 & 62 & 80 \\
\hline$A_{5}$ & 5 & 12 & 123 & 3571 & 512 & 95444 & 7 & 324 & 3 & 49 & 139 \\
\hline$A_{6}$ & 2 & 24 & 251 & 582 & 580 & 126303 & 11 & 351 & 4 & 30 & 178 \\
\hline$A_{7}$ & 1 & 11 & 82 & 24 & 711 & 175351 & 14 & 345 & 2 & 5 & 3 \\
\hline$A_{8}$ & 5 & 29 & 143 & 1731 & 484 & 56558 & 14 & 329 & 3 & 56 & 65 \\
\hline$\vdots$ & $\vdots$ & $\vdots$ & $\vdots$ & $\vdots$ & $\vdots$ & $\vdots$ & $\vdots$ & $\vdots$ & $\vdots$ & $\vdots$ & $\vdots$ \\
\hline$A_{17}$ & 4 & 17 & 151 & 3548 & 736 & 124464 & 5 & 318 & 3 & 64 & 20 \\
\hline$A_{18}$ & 1 & 3 & 37 & 24 & 932 & 33599 & 1 & 379 & 3 & 5 & 22 \\
\hline$A_{19}$ & 9 & 26 & 296 & 2530 & 547 & 90063 & 22 & 285 & 5 & 53 & 67 \\
\hline$A_{20}$ & 5 & 23 & 301 & 2201 & 587 & 130363 & 4 & 276 & 5 & 50 & 50 \\
\hline
\end{tabular}

Table 4: Normalized criteria values for twenty alternative warehouse locations.

\begin{tabular}{|c|c|c|c|c|c|c|c|c|c|c|c|}
\hline$A_{k}$ & $x_{1}^{(k) *}$ & $x_{2}^{(k) *}$ & $x_{3}^{(k) *}$ & $x_{4}^{(k) *}$ & $x_{5}^{(k) *}$ & $y_{1}^{(k) *}$ & $y_{2}^{(k) *}$ & $y_{3}^{(k) *}$ & $y_{4}^{(k) *}$ & $y_{5}^{(k) *}$ & $y_{6}^{(k) *}$ \\
\hline$A_{1}$ & 0.88 & 0.00 & 0.05 & 0.20 & 0.52 & 0.02 & 0.16 & 0.11 & 1.00 & 1.00 & 0.04 \\
\hline$A_{2}$ & 3.88 & 0.16 & 0.07 & 0.00 & 0.48 & 0.02 & 0.57 & 0.30 & 1.00 & 0.04 & 0.06 \\
\hline$A_{3}$ & 4.88 & 0.03 & 0.16 & 0.00 & 0.36 & 0.00 & 0.20 & 0.07 & 0.25 & 0.04 & 0.02 \\
\hline$A_{4}$ & 3.88 & 0.06 & 0.11 & 0.00 & 0.25 & 0.00 & 0.20 & 0.00 & 0.75 & 0.00 & 0.03 \\
\hline$A_{5}$ & 4.88 & 0.16 & 0.19 & 0.00 & 0.78 & 0.08 & 0.11 & 0.53 & 0.50 & 0.03 & 0.02 \\
\hline$A_{6}$ & 1.88 & 0.33 & 0.46 & 0.01 & 0.57 & 0.12 & 0.05 & 0.43 & 0.75 & 0.10 & 0.01 \\
\hline$A_{7}$ & 0.88 & 0.14 & 0.11 & 0.20 & 0.29 & 0.17 & 0.03 & 0.45 & 0.25 & 1.00 & 1.00 \\
\hline$A_{8}$ & 4.88 & 0.40 & 0.23 & 0.00 & 0.88 & 0.04 & 0.03 & 0.52 & 0.50 & 0.01 & 0.04 \\
\hline$\ldots$ & $\cdots$ & $\ldots$ & $\ldots .$. & $\ldots .$. & ..... & $\ldots$. & $\ldots$ & $\ldots .$. & $\ldots .$. & $\ldots .$. & $\ldots$ \\
\hline$\cdots$ & $\cdots$ & $\ldots$ & ..... & $\cdots .$. & $\ldots .$. & $\ldots$. & $\ldots$ & $\ldots .$. & $\ldots .$. & $\ldots .$. & $\ldots .$. \\
\hline$\ldots$ & $\cdots$ & $\ldots$ & ..... & $\ldots .$. & ..... & $\ldots$. & $\ldots$ & $\ldots .$. & $\ldots .$. & $\ldots .$. & $\ldots .$. \\
\hline$A_{17}$ & 3.88 & 0.22 & 0.25 & 0.00 & 0.25 & 0.11 & 0.19 & 0.56 & 0.50 & 0.00 & 0.15 \\
\hline$A_{18}$ & 0.88 & 0.02 & 0.01 & 0.20 & 0.00 & 0.01 & 1.00 & 0.33 & 0.50 & 1.00 & 0.13 \\
\hline$A_{19}$ & 8.88 & 0.36 & 0.55 & 0.00 & 0.67 & 0.08 & 0.00 & 0.73 & 1.00 & 0.02 & 0.04 \\
\hline$A_{20}$ & 4.88 & 0.31 & 0.56 & 0.00 & 0.56 & 0.12 & 0.25 & 0.78 & 1.00 & 0.02 & 0.06 \\
\hline
\end{tabular}

Table 5: Expert priorities.

\begin{tabular}{cccccccccccc}
\hline$E_{s}$ & $\left(x_{1}\right)_{r}^{s}$ & $\left(x_{2}\right)_{r}^{s}$ & $\left(x_{3}\right)_{r}^{s}$ & $\left(x_{4}\right)_{r}^{s}$ & $\left(x_{5}\right)_{r}^{s}$ & $\left(y_{1}\right)_{r}^{s}$ & $\left(y_{2}\right)_{r}^{s}$ & $\left(y_{3}\right)_{r}^{s}$ & $\left(y_{4}\right)_{r}^{s}$ & $\left(y_{5}\right)_{r}^{s}$ & $\left(y_{6}\right)_{r}^{s}$ \\
\hline$E_{1}$ & 1 & 4 & 3 & 2 & 5 & 1 & 3 & 6 & 5 & 2 \\
$E_{2}$ & 3 & 4 & 2 & 1 & 5 & 1 & 6 & 2 & 3 & 4 \\
$E_{3}$ & 2 & 3 & 1 & 4 & 5 & 1 & 2 & 3 & 4 & 5 & 6 \\
$E_{4}$ & 5 & 1 & 4 & 2 & 3 & 3 & 4 & 6 & 2 & 1 & 5 \\
$E_{5}$ & 5 & 1 & 3 & 2 & 4 & 6 & 3 & 4 & 2 & 1 \\
\hline
\end{tabular}


Table 6: Priority rankings of criteria for each expert.

\begin{tabular}{lll}
\hline$E_{s}$ & \multicolumn{1}{c}{$\left(p_{i t}\right)^{s}$} & \multicolumn{1}{c}{$\left(p_{j z}\right)^{s}$} \\
\hline$E_{1}$ & $x_{(1)}^{1}>x_{(4)}^{1}>x_{(3)}^{1}>x_{(2)}^{1}>x_{(5)}^{1}$ & $y_{(1)}^{1}>y_{(5)}^{1}>y_{(2)}^{1}>y_{(6)}^{1}>y_{(4)}^{1}>y_{(3)}^{1}$ \\
$E_{2}$ & $x_{(4)}^{2}>x_{(3)}^{2}>x_{(1)}^{2}>x_{(2)}^{2}>x_{(5)}^{2}$ & $y_{(1)}^{2}>y_{(3)}^{2}>y_{(4)}^{2}>y_{(5)}^{2}>y_{(6)}^{2}>y_{(2)}^{2}$ \\
$E_{3}$ & $x_{(3)}^{3}>x_{(1)}^{3}>x_{(2)}^{3}>x_{(4)}^{3}>x_{(5)}^{3}$ & $y_{(1)}^{3}>y_{(2)}^{3}>y_{(3)}^{3}>y_{(4)}^{3}>y_{(5)}^{3}>y_{(6)}^{3}$ \\
$E_{4}$ & $x_{(2)}^{4}>x_{(4)}^{4}>x_{(5)}^{4}>x_{(3)}^{4}>x_{(1)}^{4}$ & $y_{(5)}^{4}>y_{(4)}^{4}>y_{(1)}^{4}>y_{(2)}^{4}>y_{(6)}^{4}>y_{(3)}^{4}$ \\
$E_{5}$ & $x_{(2)}^{5}>x_{(4)}^{5}>x_{(3)}^{5}>x_{(5)}^{5}>x_{(1)}^{5}$ & $y_{(5)}^{1}>y_{(4)}^{1}>y_{(2)}^{1}>y_{(3)}^{1}>y_{(6)}^{1}>y_{(1)}^{1}$ \\
\hline
\end{tabular}

Priority matrix for each expert for the firm related criteria group is formed according to the rankings given in Table 6 as seen in Eq. (14), (15), (16), (17), (18) as an example. Same matrices are established for the environmental criteria group.

$$
\begin{aligned}
& {\left[P_{X}^{1}\right]_{5 \times 5}=\left[\begin{array}{lllll}
0 & 1 & 1 & 1 & 1 \\
0 & 0 & 0 & 0 & 1 \\
0 & 1 & 0 & 0 & 1 \\
0 & 1 & 1 & 0 & 1 \\
0 & 0 & 0 & 0 & 0
\end{array}\right]} \\
& {\left[P_{X}^{2}\right]_{5 \times 5}=\left[\begin{array}{lllll}
0 & 1 & 0 & 0 & 1 \\
0 & 0 & 0 & 0 & 1 \\
1 & 0 & 0 & 0 & 1 \\
1 & 1 & 1 & 0 & 1 \\
0 & 0 & 0 & 0 & 0
\end{array}\right]} \\
& {\left[P_{X}^{3}\right]_{5 \times 5}=\left[\begin{array}{lllll}
0 & 1 & 0 & 1 & 1 \\
0 & 0 & 0 & 1 & 1 \\
1 & 1 & 0 & 1 & 1 \\
0 & 0 & 0 & 0 & 1 \\
0 & 0 & 0 & 0 & 0
\end{array}\right]} \\
& {\left[P_{X}^{4}\right]_{5 \times 5}=\left[\begin{array}{lllll}
0 & 0 & 0 & 0 & 0 \\
1 & 0 & 1 & 1 & 1 \\
1 & 0 & 0 & 0 & 0 \\
1 & 0 & 1 & 0 & 1 \\
1 & 0 & 1 & 0 & 0
\end{array}\right]} \\
& {\left[P_{X}^{5}\right]_{5 \times 5}=\left[\begin{array}{lllll}
0 & 0 & 0 & 0 & 0 \\
1 & 0 & 1 & 1 & 1 \\
1 & 0 & 0 & 0 & 1 \\
1 & 0 & 1 & 0 & 1 \\
1 & 0 & 0 & 0 & 0
\end{array}\right]}
\end{aligned}
$$

Step 6. Form the priority matrix for each expert for each criterion.

The priority matrix for each expert is given in Table 6. For example, for the first expert $\left(E_{1}\right), x_{1}$ is at the first rank, $x_{4}$ is at the second rank, $x_{3}$ is at the third rank, $x_{2}$ is at the fourth rank and $x_{5}$ is at the fifth rank. Ranking of environmental criteria group can be interpreted in a same manner.

Step 7. Find the distance between each expert's priority.

Priority distance for each expert for the firm related criteria group are computed as in Eq.(6) and $\rho_{X}^{1}$ is given in Eq.(19) as an example.

$$
\rho_{X}^{1}=\sum_{s=1}^{5} \sum_{i=1}^{6} \sum_{t=1}^{6}\left|\left(p_{i t}\right)^{1}-\left(p_{i t}\right)^{s}\right|=5
$$

Since, the second expert provides the minimum value obtained as in Eq.(6) $\left(\rho_{X}=28\right)$, the priority ranking of the second expert is accepted as the priority median component for the firm related criteria group as $x_{4}>x_{3}>x_{1}>x_{2}>x_{5}$. Additionally, fourth expert provides the minimum value obtained as in Eq.(8) $\left(\rho_{Y}=50\right)$. Therefore, the priority ranking of the fourth expert is accepted as the priority median component for environmental criteria group as $y_{5}>y_{4}>y_{1}>y_{2}>y_{6}>y_{3}$.

Step 8. Assign criteria weights according to the median priority components.

Each expert determines weights of criteria according to the median priority component for each criterion group satisfying median priority ranking and $w_{x_{1}}+w_{x_{2}}+w_{x_{3+}} \ldots+w_{x_{n}}=$ $1, \quad w_{y_{1}}+w_{y_{2}}+w_{y_{3}}+\cdots+w_{y_{4}}=1$.

There are 25 weight combinations satisfying condition $w_{x 4} \geq$ $w_{x 3} \geq w_{x 1} \geq w_{x 2} \geq w_{x 5}$ and 25 weight combinations satisfying condition $w_{y 5} \geq w_{y 4} \geq w_{y 1} \geq w_{y 2} \geq w_{y 6} \geq w_{y 3}$. These weights are presented in Table 7 for firm related criteria group and Table 8 for environmental criteria group. Weight combinations are determined by the authors randomly.

Step 9. Form the weighted normalized vector of alternatives for each weight set.

Weighted normalized vector of alternatives for the firm related criteria group $v_{X}$ and for environmental criteria group $v_{Y}$ are obtained using Eq.(9) and Eq.(10) as in Table 9 and Table 10 respectively.

Step 10. Rank the alternatives.

Totally, $625(25 \times 25)$ cases were evaluated in terms of $s^{(k)}$ values. As seen in Table $11, s^{(k)}$ gains its minimum value as 2.77. This value was obtained from the fifth column of $X$ criteria, eleventh row of $Y$ criteria. According to this column and this row, weights are obtained as follows:

$$
\begin{gathered}
w_{x 1}=0, w_{x 2}=0, w_{x 3}=0,3, w_{x 4}=0,7, w_{x 5}=0 \\
w_{y 1}=0.1, w_{y 2}=0.1, w_{y 3}=0, w_{y 4}=0.1, w_{y 5}=0.6, w_{y 6} \\
=0.1
\end{gathered}
$$

Final ranking of the alternatives were obtained as in Table 12. Alternative 11 is the best warehouse location for the electricity distribution company.

As seen from Table 12, ranking order of the alternatives is $\mathrm{A}_{11}>\mathrm{A}_{7}>\mathrm{A}_{18}>\mathrm{A}_{1}>\mathrm{A}_{20}>\mathrm{A}_{13}>\mathrm{A}_{6}>\mathrm{A}_{15}>\mathrm{A}_{19}>\mathrm{A}_{12}>$ $A_{14}>A_{9}>A_{2}>A_{10}>A_{16}>A_{17}>A_{5}>A_{8}>A_{4}>A_{3}$. 
Table 7: Weight combinations for firm related criteria group according to $E_{2}$.

\begin{tabular}{|c|c|c|c|c|c|c|}
\hline \multirow{3}{*}{$\begin{array}{c}\text { Weight } \\
\text { Combination } \\
\text { Number }\end{array}$} & \multicolumn{6}{|c|}{$\begin{array}{c}x_{4}>x_{3}>x_{1}>x_{2}>x_{5} \\
\text { (second expert's ranking) }\end{array}$} \\
\hline & \multicolumn{6}{|c|}{$w_{x_{4}} \geq w_{x_{3}} \geq w_{x_{1}} \geq w_{x_{2}} \geq w_{x_{5}}$} \\
\hline & $w_{x_{1}}$ & $w_{x_{2}}$ & $w_{x_{3}}$ & $w_{x_{4}}$ & $w_{x_{5}}$ & Sum \\
\hline 1 & 0.0 & 0.0 & 0.0 & 1.0 & 0.0 & 1.0 \\
\hline 2 & 0.0 & 0.0 & 0.1 & 0.9 & 0.0 & 1.0 \\
\hline 3 & 0.1 & 0.0 & 0.1 & 0.8 & 0.0 & 1.0 \\
\hline 4 & 0.0 & 0.0 & 0.2 & 0.8 & 0.0 & 1.0 \\
\hline 5 & 0.0 & 0.0 & 0.3 & 0.7 & 0.0 & 1.0 \\
\hline 6 & 0.1 & 0.1 & 0.1 & 0.7 & 0.0 & 1.0 \\
\hline 7 & 0.1 & 0.0 & 0.2 & 0.7 & 0.0 & 1.0 \\
\hline$\ldots$ & $\ldots$ & $\cdots$ & $\cdots$. & $\cdots$ & $\ldots$ & $\ldots$ \\
\hline$\ldots$ & $\ldots$ & $\ldots$ & $\ldots$ & $\ldots$ & $\ldots$ & $\ldots$ \\
\hline$\ldots$ & $\ldots$ & $\ldots$ & $\ldots$ & $\ldots$ & $\ldots$ & $\ldots$ \\
\hline$\ldots$ & $\ldots$ & $\ldots$ & $\ldots$ & $\ldots$ & $\ldots$ & $\ldots$ \\
\hline 22 & 0.2 & 0.2 & 0.2 & 0.4 & 0.0 & 1.0 \\
\hline 23 & 0.2 & 0.1 & 0.2 & 0.4 & 0.1 & 1.0 \\
\hline 24 & 0.3 & 0.1 & 0.3 & 0.3 & 0.0 & 1.0 \\
\hline 25 & 0.2 & 0.2 & 0.3 & 0.3 & 0.0 & 1.0 \\
\hline
\end{tabular}

Table 8: Weight combinations for environmental criteria group according to $E_{4}$.

\begin{tabular}{|c|c|c|c|c|c|c|c|}
\hline \multirow{3}{*}{ Weight Combination Number } & \multicolumn{7}{|c|}{$\begin{array}{c}y_{5}>y_{4}>y_{1}>y_{2}>y_{6}>y_{3} \\
\text { (fourth expert's ranking) }\end{array}$} \\
\hline & \multicolumn{7}{|c|}{$w_{y_{5}} \geq w_{y_{4}} \geq w_{y_{1}} \geq w_{y_{2}} \geq w_{y_{6}} \geq w_{y_{3}}$} \\
\hline & $w_{y_{1}}$ & $w_{y_{2}}$ & $w_{y_{3}}$ & $w_{y_{4}}$ & $w_{y_{5}}$ & $w_{y_{6}}$ & Sum \\
\hline 1 & 0.0 & 0.0 & 0.0 & 1.0 & 0.0 & 0.0 & 1. \\
\hline 2 & 0.0 & 0.0 & 0.1 & 0.9 & 0.0 & 0.0 & 1.0 \\
\hline 3 & 0.1 & 0.0 & 0.1 & 0.8 & 0.0 & 0.0 & 1. \\
\hline 4 & 0.0 & 0.0 & 0.2 & 0.8 & 0.0 & 0.0 & 1. \\
\hline 5 & 0.0 & 0.0 & 0.3 & 0.7 & 0.0 & 0.0 & 1. \\
\hline 6 & 0.1 & 0.1 & 0.1 & 0.7 & 0.0 & 0.0 & 1. \\
\hline 7 & 0.1 & 0.0 & 0.2 & 0.7 & 0.0 & 0.0 & 1. \\
\hline$\ldots$ & $\ldots$ & $\ldots$. & $\ldots$ & $\ldots$ & $\ldots$ & $\ldots$ & $\ldots$ \\
\hline$\ldots$ & $\ldots$ & $\ldots$. & $\ldots$ & $\ldots$ & $\ldots$ & $\ldots$ & $\ldots$ \\
\hline$\ldots$ & $\ldots$ & $\ldots$. & $\ldots$ & $\ldots$ & $\ldots$ & $\ldots$ & ... \\
\hline$\ldots$ & $\ldots$ & $\ldots$ & $\ldots$ & $\ldots$ & $\ldots$ & $\ldots$ & $\ldots$ \\
\hline 22 & 0.2 & 0.2 & 0.2 & 0.4 & 0.0 & 0.0 & 1. \\
\hline 23 & 0.2 & 0.1 & 0.2 & 0.4 & 0.1 & 0.1 & 1. \\
\hline 24 & 0.3 & 0.1 & 0.3 & 0.3 & 0.0 & 0.1 & 1. \\
\hline 25 & 0.2 & 0.2 & 0.3 & 0.3 & 0.0 & 0.0 & 1.0 \\
\hline
\end{tabular}

Table 9: Values of $v_{x}$.

\begin{tabular}{|c|c|c|c|c|c|c|c|c|c|c|}
\hline \multirow[b]{2}{*}{$A_{k}$} & \multicolumn{10}{|c|}{ Weight Combination Numbers } \\
\hline & 1 & 2 & 3 & 4 & 5 & $\ldots$ & 22 & 23 & 24 & 25 \\
\hline $\mathrm{A}_{1}$ & 0.20 & 0.18 & 0.25 & 0,17 & 0.15 & $\ldots$ & 0.26 & 0.32 & 0.34 & 0.25 \\
\hline $\mathrm{A}_{2}$ & 0.00 & 0.01 & 0.40 & 0,01 & 0.02 & $\ldots$ & 0.82 & 0.85 & 1.20 & 0.83 \\
\hline $\mathrm{A}_{3}$ & 0.00 & 0.02 & 0.50 & 0.03 & 0.05 & $\ldots$ & 1.01 & 1.05 & 1.51 & 1.03 \\
\hline $\mathrm{A}_{4}$ & 0.00 & 0.01 & 0.40 & 0.02 & 0.03 & $\ldots$ & 0.81 & 0.83 & 1.20 & 0.82 \\
\hline$A_{5}$ & 0.00 & 0.02 & 0.51 & 0.04 & 0.06 & $\ldots$ & 1.04 & 1.11 & 1.54 & 1.06 \\
\hline$A_{6}$ & 0.01 & 0.05 & 0.24 & 0.10 & 0.14 & $\ldots$ & 0.53 & 0.56 & 0.73 & 0.58 \\
\hline$\ldots$ & $\ldots$ & $\ldots$ & $\ldots$ & $\ldots$ & $\ldots$ & $\ldots$ & $\ldots$ & $\ldots$ & $\ldots$ & $\ldots$ \\
\hline$\ldots$ & $\cdots$ & $\cdots$ & $\cdots$ & $\ldots$ & $\cdots$ & $\cdots$ & $\cdots$ & $\cdots$ & $\cdots$ & $\ldots$ \\
\hline$A_{12}$ & 0.00 & 0.02 & 0.61 & 0.05 & 0.07 & $\ldots$ & 1.25 & 1.27 & 1.85 & 1.27 \\
\hline $\mathrm{A}_{13}$ & 0.00 & 0.06 & 0.65 & 0.12 & 0.17 & $\ldots$ & 1,39 & 1.38 & 1.99 & 1.45 \\
\hline $\mathrm{A}_{14}$ & 0.00 & 0.04 & 0.73 & 0.09 & 0.13 & $\ldots$ & 1.49 & 1.57 & 2.20 & 1.53 \\
\hline $\mathrm{A}_{15}$ & 0.00 & 0.05 & 0.94 & 0.10 & 0.15 & $\ldots$ & 1,93 & 1.98 & 2.84 & 1.98 \\
\hline $\mathrm{A}_{16}$ & 0.00 & 0.03 & 0.72 & 0.06 & 0.08 & $\ldots$ & 1.49 & 1.50 & 2.17 & 1.52 \\
\hline$A_{17}$ & 0.00 & 0.02 & 0.41 & 0.05 & 0.07 & $\ldots$ & 0.87 & 0.87 & 1.26 & 0.89 \\
\hline $\mathrm{A}_{18}$ & 0.20 & 0.18 & 0.25 & 0.16 & 0.14 & $\ldots$ & 0.26 & 0.26 & 0.33 & 0.24 \\
\hline
\end{tabular}


Table 9: Continued.

\begin{tabular}{rcccccccccc}
\hline & \multicolumn{10}{c}{ Weight Combination Numbers } \\
\cline { 2 - 12 } $\mathrm{A}_{\mathrm{k}}$ & 1 & 2 & 3 & 4 & 5 & $\ldots$ & 22 & 23 & 24 & 25 \\
\cline { 2 - 11 }$_{19}$ & 0.00 & 0.06 & 0.94 & 0.11 & 0.17 & $\ldots$ & 1.96 & 1.99 & 2.86 & 2.01 \\
$\mathrm{~A}_{20}$ & 0.00 & 0.06 & 0.54 & 0.11 & 0.17 & $\ldots$ & 1.15 & 1.17 & 1.66 & 1.21 \\
\hline
\end{tabular}

Table 10: Values of $v_{y}$.

\begin{tabular}{|c|c|c|c|c|c|c|c|c|c|c|}
\hline \multirow[b]{2}{*}{$A_{k}$} & \multicolumn{10}{|c|}{ Weight Combination Numbers } \\
\hline & 1 & 2 & 3 & 4 & 5 & $\ldots$ & 22 & 23 & 24 & 25 \\
\hline$A_{1}$ & 1.00 & 1.00 & 1.00 & 0.90 & 0.82 & $\ldots$ & 0.71 & 0.71 & 0.72 & 0.64 \\
\hline$A_{2}$ & 0.04 & 0.14 & 0.23 & 0.13 & 0.19 & $\ldots$ & 0.32 & 0.33 & 0.38 & 0.33 \\
\hline$A_{3}$ & 0.04 & 0.06 & 0.08 & 0.06 & 0.07 & $\ldots$ & 0.09 & 0.09 & 0.11 & 0.11 \\
\hline$A_{4}$ & 0.00 & 0.08 & 0.15 & 0.08 & 0.10 & $\ldots$ & 0.23 & 0.23 & 0.25 & 0.19 \\
\hline$A_{5}$ & 0.03 & 0.07 & 0.12 & 0.08 & 0.09 & $\ldots$ & 0.18 & 0.18 & 0.18 & 0.15 \\
\hline$A_{6}$ & 0.10 & 0.16 & 0.23 & 0.17 & 0.16 & $\ldots$ & 0.30 & 0.29 & 0.28 & 0.22 \\
\hline$\ldots$ & $\ldots$ & $\ldots$ & $\ldots$ & $\ldots$ & $\ldots$ & $\ldots$ & $\ldots$ & $\ldots$ & $\ldots$ & ... \\
\hline $\mathrm{A}_{13}$ & 0.02 & 0.07 & 0.11 & 0.12 & 0.13 & $\ldots$ & 0.32 & 0.27 & 0.22 & 0.24 \\
\hline $\mathrm{A}_{14}$ & 0.03 & 0.10 & 0.18 & 0.10 & 0.11 & $\ldots$ & 0.24 & 0.25 & 0.26 & 0.19 \\
\hline $\mathrm{A}_{15}$ & 0.01 & 0.11 & 0.21 & 0.11 & 0.13 & $\ldots$ & 0.32 & 0.32 & 0.34 & 0.25 \\
\hline $\mathrm{A}_{16}$ & 0.03 & 0.05 & 0.07 & 0.07 & 0.07 & $\ldots$ & 0.15 & 0.15 & 0.14 & 0.12 \\
\hline $\mathrm{A}_{17}$ & 0.00 & 0.05 & 0.10 & 0.06 & 0.08 & $\ldots$ & 0.18 & 0.19 & 0.19 & 0.16 \\
\hline $\mathrm{A}_{18}$ & 1.00 & 0.95 & 0.90 & 0.85 & 0.85 & $\ldots$ & 0.55 & 0.57 & 0.66 & 0.70 \\
\hline $\mathrm{A}_{19}$ & 0.02 & 0.11 & 0.21 & 0.12 & 0.12 & $\ldots$ & 0.33 & 0.33 & 0.32 & 0.22 \\
\hline $\mathrm{A}_{20}$ & 0.02 & 0.12 & 0.22 & 0.13 & 0.15 & $\ldots$ & 0.35 & 0.34 & 0.35 & 0.28 \\
\hline
\end{tabular}

Table 11: $s^{(k)}$ values for all possible weights combinations.

\begin{tabular}{|c|c|c|c|c|c|c|c|c|c|c|}
\hline \multicolumn{11}{|c|}{ Weight combinations } \\
\hline $\mathrm{y} / \mathrm{x}$ & 1 & 2 & 3 & 4 & 5 & $\ldots$ & 22 & 23 & 24 & 25 \\
\hline 1 & 2.85 & 2.84 & 10.79 & 3.21 & 3.71 & $\ldots$ & 20.46 & 20.99 & 28.88 & 20.99 \\
\hline 2 & 3.81 & 3.38 & 9.66 & 3.11 & 3.29 & $\ldots$ & 19.30 & 19.79 & 27.70 & 19.83 \\
\hline 3 & 4.76 & 4.34 & 8.56 & 3.96 & 3.72 & $\ldots$ & 18.20 & 18.66 & 26.60 & 18.73 \\
\hline 4 & 3.65 & 3.20 & 9.26 & 2.81 & 2.91 & $\ldots$ & 18.90 & 19.39 & 27.30 & 19.43 \\
\hline 5 & 3.86 & 3.42 & 8.83 & 2.97 & 2.86 & $\ldots$ & 18.47 & 18.93 & 26.87 & 19.00 \\
\hline 6 & 4.60 & 4.16 & 8.16 & 3.77 & 3.40 & $\ldots$ & 17.80 & 18.26 & 26.20 & 18.33 \\
\hline 7 & 5.71 & 5.30 & 7.57 & 4.91 & 4.56 & $\ldots$ & 17.10 & 17.55 & 25.50 & 17.63 \\
\hline 8 & 6.67 & 6.26 & 6.65 & 5.87 & 5.49 & $\ldots$ & 15.99 & 16.45 & 24.39 & 16.52 \\
\hline 9 & 5.55 & 5.11 & 7.17 & 4.73 & 4.35 & $\ldots$ & 16.70 & 17.16 & 25.10 & 17.23 \\
\hline 10 & 4.44 & 3.99 & 7.76 & 3.59 & 3.21 & $\ldots$ & 17.40 & 17.86 & 25.80 & 17.93 \\
\hline 11 & 3.84 & 3.40 & 8.68 & 2.95 & 2.77 & $\ldots$ & 18.32 & 18.78 & 26.72 & 18.85 \\
\hline$\ldots$ & $\ldots$ & ... & ... & $\ldots$ & ... & $\ldots$ & $\ldots$ & $\ldots$ & ... & ... \\
\hline$\ldots$ & $\ldots$ & $\ldots$ & $\ldots$ & $\ldots$ & $\ldots$ & $\ldots$ & $\ldots$ & $\ldots$ & $\ldots$ & $\ldots$ \\
\hline 22 & 5.23 & 4.79 & 6.38 & 4.36 & 3.98 & $\ldots$ & 15.90 & 16.36 & 24.30 & 16.43 \\
\hline 23 & 5.37 & 4.93 & 6.61 & 4.52 & 4.14 & $\ldots$ & 16.15 & 16.61 & 24.55 & 16.68 \\
\hline 24 & 5.75 & 5.30 & 6.56 & 4.86 & 4.44 & $\ldots$ & 16.12 & 16.58 & 24.52 & 16.65 \\
\hline 25 & 4.87 & 4.42 & 6.89 & 3.98 & 3.54 & $\ldots$ & 16.53 & 16.99 & 24.93 & 17.06 \\
\hline
\end{tabular}

Table 12: Final ranking of alternatives setting the optimal solution.

\begin{tabular}{|c|c|c|c|c|c|c|c|c|c|c|c|c|c|c|c|}
\hline \multirow{3}{*}{$A_{k}$} & \multicolumn{11}{|c|}{ Weights } & \multirow{3}{*}{$\mathrm{v}_{\mathrm{X}}^{(\mathrm{k})}$} & \multirow{3}{*}{$\mathrm{v}_{\mathrm{y}}^{(\mathrm{k})}$} & \multirow{3}{*}{$\mathrm{v}_{\mathrm{x}}^{(\mathrm{k})}+\mathrm{v}_{\mathrm{y}}^{(\mathrm{k})}$} & \multirow{3}{*}{ Rank } \\
\hline & 0 & 0 & 0.3 & 0.7 & 0 & 0.1 & 0.1 & 0 & 0.1 & 0.6 & 0.1 & & & & \\
\hline & $\mathrm{x}_{1}$ & $\mathrm{x}_{2}$ & $\mathrm{x}_{3}$ & $\mathrm{x}_{4}$ & $\mathrm{x}_{5}$ & $\mathrm{y}_{1}$ & $\mathrm{y}_{2}$ & $\mathrm{y}_{3}$ & $\mathrm{y}_{4}$ & $\mathrm{y}_{5}$ & $\mathrm{y}_{6}$ & & & & \\
\hline $\mathrm{A}_{11}$ & 0.88 & 1.00 & 1.00 & 1.00 & 0.59 & 1.00 & 0.28 & 1.00 & 0.50 & 1.00 & 0.00 & 1.00 & 0.78 & 1.78 & 1 \\
\hline $\mathrm{A}_{7}$ & 0.88 & 0.14 & 0.11 & 0.20 & 0.29 & 0.17 & 0.03 & 0.45 & 0.25 & 1.00 & 1.00 & 0.17 & 0.74 & 0.92 & 2 \\
\hline $\mathrm{A}_{18}$ & 0.88 & 0.02 & 0.01 & 0.20 & 0.00 & 0.01 & 1.00 & 0.33 & 0.50 & 1.00 & 0.13 & 0.14 & 0.76 & 0.91 & 3 \\
\hline $\mathrm{A}_{20}$ & 4.88 & 0.31 & 0.56 & 0.00 & 0.56 & 0.12 & 0.25 & 0.78 & 1.00 & 0.02 & 0.06 & 0.17 & 0.16 & 0.33 & 5 \\
\hline $\mathrm{A}_{13}$ & 5.88 & 0.51 & 0.58 & 0.00 & 0.41 & 0.56 & 0.10 & 0.98 & 0.50 & 0.02 & 0.01 & 0.17 & 0.13 & 0.30 & 6 \\
\hline $\mathrm{A}_{6}$ & 1.88 & 0.33 & 0.46 & 0.01 & 0.57 & 0.12 & 0.05 & 0.43 & 0.75 & 0.10 & 0.01 & 0.14 & 0.15 & 0.29 & 7 \\
\hline $\mathrm{A}_{15}$ & 8.88 & 0.30 & 0.50 & 0.00 & 0.80 & 0.03 & 0.20 & 0.91 & 1.00 & 0.01 & 0.12 & 0.15 & 0.14 & 0.29 & 8 \\
\hline $\mathrm{A}_{19}$ & 8.88 & 0.36 & 0.55 & 0.00 & 0.67 & 0.08 & 0.00 & 0.73 & 1.00 & 0.02 & 0.04 & 0.17 & 0.12 & 0.29 & 9 \\
\hline $\mathrm{A}_{12}$ & 5.88 & 0.15 & 0.23 & 0.00 & 0.36 & 0.03 & 0.45 & 0.88 & 1.00 & 0.03 & 0.20 & 0.07 & 0.19 & 0.25 & 10 \\
\hline $\mathrm{A}_{9}$ & 4.88 & 0.15 & 0.00 & 0.00 & 1.00 & 0.13 & 0.61 & 0.45 & 1.00 & 0.06 & 0.00 & 0.00 & 0.21 & 0.21 & 12 \\
\hline $\mathrm{A}_{2}$ & 3.88 & 0.16 & 0.07 & 0.00 & 0.48 & 0.02 & 0.57 & 0.30 & 1.00 & 0.04 & 0.06 & 0.02 & 0.19 & 0.21 & 13 \\
\hline $\mathrm{A}_{10}$ & 3.88 & 0.15 & 0.31 & 0.00 & 0.62 & 0.14 & 0.53 & 0.24 & 0.00 & 0.03 & 0.06 & 0.09 & 0.09 & 0.18 & 14 \\
\hline $\mathrm{A}_{16}$ & 6.88 & 0.29 & 0.27 & 0.00 & 0.45 & 0.20 & 0.09 & 0.38 & 0.25 & 0.03 & 0.21 & 0.08 & 0.09 & 0.17 & 15 \\
\hline
\end{tabular}


Table 12: Continued.

\begin{tabular}{|c|c|c|c|c|c|c|c|c|c|c|c|c|c|c|c|}
\hline \multirow{3}{*}{$\mathrm{A}_{\mathrm{k}}$} & \multicolumn{11}{|c|}{ Weights } & \multirow{3}{*}{$\mathrm{v}_{\mathrm{X}}{ }^{(\mathrm{k})}$} & \multirow{3}{*}{$\mathrm{v}_{\mathrm{y}}{ }^{(\mathrm{k})}$} & \multirow{3}{*}{$\mathrm{v}_{\mathrm{x}}^{(\mathrm{k})}+\mathrm{v}_{\mathrm{y}}{ }^{(\mathrm{k})}$} & \multirow{3}{*}{ Rank } \\
\hline & 0 & 0 & 0.3 & 0.7 & 0 & 0.1 & 0.1 & 0 & 0.1 & 0.6 & 0.1 & & & & \\
\hline & $\mathrm{x}_{1}$ & $\mathrm{x}_{2}$ & $\mathrm{x}_{3}$ & $\mathrm{x}_{4}$ & $\mathrm{x}_{5}$ & $\mathrm{y}_{1}$ & $\mathrm{y}_{2}$ & $\mathrm{y}_{3}$ & $\mathrm{y}_{4}$ & $\mathrm{y}_{5}$ & $\mathrm{y}_{6}$ & & & & \\
\hline $\mathrm{A}_{17}$ & 3.88 & 0.22 & 0.25 & 0.00 & 0.25 & 0.11 & 0.19 & 0.56 & 0.50 & 0.00 & 0.15 & 0.07 & 0.09 & 0.17 & 16 \\
\hline $\mathrm{A}_{5}$ & 4.88 & 0.16 & 0.19 & 0.00 & 0.78 & 0.08 & 0.11 & 0.53 & 0.50 & 0.03 & 0.02 & 0.06 & 0.09 & 0.14 & 17 \\
\hline $\mathrm{A}_{8}$ & 4.88 & 0.40 & 0.23 & 0.00 & 0.88 & 0.04 & 0.03 & 0.52 & 0.50 & 0.01 & 0.04 & 0.07 & 0.07 & 0.14 & 18 \\
\hline $\mathrm{A}_{4}$ & 3.88 & 0.06 & 0.11 & 0.00 & 0.25 & 0.00 & 0.20 & 0.00 & 0.75 & 0.00 & 0.03 & 0.03 & 0.10 & 0.13 & 19 \\
\hline $\mathrm{A}_{3}$ & 4.88 & 0.03 & 0.16 & 0.00 & 0.36 & 0.00 & 0.20 & 0.07 & 0.25 & 0.04 & 0.02 & 0.05 & 0.07 & 0.12 & 20 \\
\hline
\end{tabular}

\section{Conclusion and discussion}

Warehouse location is very significance issue for Electricity Distribution Companies, because energy is indispensable for a city. Materials which maintain the electricity grid are stored at this warehouse.

In this study, a new approach for Electricity Distribution Companies based on KEMIRA-M is proposed for warehouse location selection. KEMIRA-M is a powerful tool when alternatives are evaluated by two groups of criteria (or more) having different origin. There are 20 alternative warehouse locations which are determined by Electricity Distribution Company. According to the two groups (5 Firm Related and 6 Environmental factors) of evaluation criteria, the best alternative was determined as $\mathrm{A}_{11}$. This alternative is Çankaya region where has large population, high consumption of material, high investment amounts. This result is eligible for the expert group.

Warehouse location is very significance issue for Electricity Distribution Companies, because energy is indispensable for a city. Materials which maintain the electricity grid are stored at this warehouse.

Çankaya contains the most important region in area of electricity distribution company activity territory.

It is the center of Ankara which is the capital city of the Republic of Turkey. It is also more crowded and developing part of the region. Moreover, Presidential Complex is also located in this region. Due to the reasons mentioned, continuous energy is a significant part of the electricity distribution service. In order to provide this, to establish a new electricity material warehouse location is necessary for this.

It is seen that KEMIRA-M is convenient for location selection problems. There is no restriction related to the numbers of criteria and alternatives in this method. Additionally, decision is not only based on experts' own opinions but also criteria' quantitative and qualitative values for alternatives. Moreover, it provides decision makers ranking flexibility.

For the future studies, subjectivity in weighting procedure of KEMIRA-M may be improved. This weighting procedure can be performed in a more systematic way. Rules for assigning weights can be advanced. Additionally, KEMIRA-M can be implemented for different decision areas.

The main limitation of the proposed approach is increasing number of decision makers. If the number of decision makers increase the number of comparisons for criteria rankings is increase and this leads to spend much more time. To overcome this disadvantages, stochastic processes and coding systems may be used.

\section{References}

[1] Ramaa A, Subramanya KN, Rangaswamy TM. "Impact of warehouse management system in a supply chain". International Journal of Computer Applications, 54(1), 14-20, 2012.

[2] Škerlic S, Muha R. "Warehouse site selection in an international environment". Transport Problems, 8(2), 95-106, 2013.

[3] Demirel T, Çetin Demirel N, Kahraman C. "Multi-criteria warehouse location selection using Choquet integral". ScienceDirect Expert Systems with Applications, 37(5), 3943-3952, 2019.

[4] Drezner Z. Facility Location: A Survey of Applications and Methods. $1^{\text {nd }}$ ed New York, USA, Springer-Verlag, 1995.

[5] Han Y, Guan X, Shi L. "Optimal supply location selection and routing for emergency material delivery with uncertain demands". 2010 International Conference on Information, Networking and Automation (ICINA), Kunming, China, 18-19 October 2010.

[6] Cao Q, Di X, Zhang X. "A simulated annealing methodology to estate logistic warehouse location selection and distribution of customers' requirement". 2009 International Workshop on Intelligent Systems and Applications, USA, 30 November-2 December 2009.

[7] Liang S, Tu Q. "Location selection for time limited aeronautical emergency material depot". Proceedings of 2009 IEEE International Conference on Grey Systems and Intelligent Services, Nanjing, China, 10-12 November 2009.

[8] Feng L, Huili X, Yongjian Y. "Study on fuzzy matter-element model based on grey relevancy analysis in comprehensive evaluation of logistics center location". $16^{\text {th }}$ International Conference on Industrial Engineering and Engineering Management, Beijing, China, 21-23 October 2009.

[9] Özcan T, Çelebi N, Esnaf S. "Comparative analysis of multi-criteria decision making methodologies and implementation of a warehouse location selection problem". Science Direct Expert Systems with Applications, 38(8), 9773-9779, 2011.

[10] Natarajan Y, Dharmarajan R, Kanimozhi G, Anand M. "Comparative analysis for warehouse selection problem by using multi criteria decision making methodologies" International Conference on Application of Optimization Techniques in Engineering, At Kodaikannal, India, 27-28 September 2012.

[11] Uysal F, Tosun 0. "Selection of sustainable warehouse location in supply chain using the grey approach". International Journal of Information and Decision Sciences, 6(4), 338-353, 2015. 
[12] Aktepe A, Ersöz S. "Application of AHP-VIKOR and MOORA methods in warehouse site selection problem". Endüstri Mühendisliği Dergisi, 25(1-2), 2-15, 2014.

[13] Erbaş M, Bali Ö, Durğut T. "Tehlikeli madde depo yeri seçiminin coğrafi bilgi sistemleri açısından değerlendirilmesi". V. Uzaktan Algılama ve Coğrafi Bilgi Sistemleri Sempozyumu, İstanbul, Türkiye, 14-17 Ekim 2014.

[14] Jayant, A. "Use of grey relational analysis in solving multiple attribute decision-making problem: A case study of warehouse location selection". Advances in Industrial Engineering and Management, Research Gate, 4(2), 157-164, 2015.

[15] Malmir B, Moein R, Chaharsooghi S. "Selecting warehouse location by means of the balancing and ranking method with an interval approach". IEOM 2015-5th International Conference on Industrial Engineering and Operations Management, Proceeding, Dubai, United Arab Emirates, 3-5 March 2015.

[16] Dey B, Bairagi B, Sarkar B, Sanyal SK. "Warehouse location selection by fuzzy multi-criteria decision making methodologies based on subjective and objective criteria". International Journal of Management Science and Engineering Management, 11(4) 262-278, 2015.

[17] Mangalan AV, Kuriakose S, Mohamed H. "Optimal location of warehouse using weighted MOORA approach". 2016 International Conference on Electrical, Electronics, and Optimization Techniques (ICEEOT), Chennai, India, 3-5 March 2016

[18] Zhu Y, Xue, X, Zhang K, Mao S, Gao H. “Applying probabilistic model checking to express delivery location selection and optimization". 2016 IEEE 13 th International Conference on e-Business Engineering (ICEBE), Macau, China, 4-6 November 2016.

[19] Devangan LK. "An integrated production, inventory, warehouse location and distribution model". Journal of Operations and Supply Chain Management, 9(2), 17-27, 2016.

[20] Özbek A, Erol E. “COPRAS ve MOORA yöntemlerinin depo yeri seçim problemine uygulanması". DergiPark Akademik, 2(1), 23-42, 2016.

[21] Ercan Cömert S, Yener F. "Using fuzzy analytical hierarchy process for warehouse location selection in a food company". International Journal of Economics and Administrative Sciences, 2(2), 161-177, 2016.

[22] Sezer F, Bali O, Gürol P. "Hazardous materials warehouse selection as a multiple criteria decision making problem." Journal of Economics Bibliography, 3(1), 63-73, 2016.

[23] Dey B, Bairagi B, Sarkarb B, Sanyal SK." Group heterogeneity in multi member decision making model with an application to warehouse location selection in a supply chain". Computers \& Industrial Engineering, Elsevier, 105, 101-122, 2017.

[24] He J, Feng C, Hu D, Liang L. "A decision model for emergency warehouse location based on a novel stochastic MCDA method: evidence from China". Hindawi Mathematical Problems in Engineering, 1(1), 1-10, 2017.

[25] Gül E, Eren T. "Warehouse selection with analytic hierarchy process method and goal programming in logistic distribution network problems". Harran University Journal of Engineering, 1(1), 1-13, 2017.
[26] Shukla G, Hota HS, Sharma AS. "Multicriteria decision making based solution to location selection for modern agri-warehouses". International Conference on Inventive Communication and Computational Technologies, Coimbatore, India, 10-11 March 2017

[27] Büyüközkan G, Uztürk D. “Combined QFD TOPSIS approach with 2-tuple linguistic information for warehouse selection". 2017 IEEE International Conference on Fuzzy Systems (FUZZ-IEEE), Naples, Italy, 9-12 July 2017.

[28] Chen C, Liu J, Li Q, Wang Y, Xiong H, Wu S. “Warehouse site selection for online retailers in inter-connected warehouse networks". IEEE International Conference on Data Mining, New Orleans, USA, 18-11 November 2017

[29] Izdebski M, Jacyna-Gołda I, Wasiak M, Jachimowski R, Kłodawski M, Pyza D, Zak J. "The application of the genetic algorithm to multı-criteria warehouses location problems on the logistics network". Transport, 33(3), 741-750, 2018.

[30] Jha M, Raut R, Gardas B, Raut V. "A sustainable warehouse selection: An interpretive structural modelling approach" International Journal of Procurement Management, 11(2), 201-232, 2018.

[31] Lin YS, Wanga KJ. "A two-stage stochastic optimization model for warehouse configuration and inventory policy of deteriorating items". ScienceDirect Computers \& Industrial Engineering, 120, 83-93, 2018.

[32] Brunauda B, Bassettb MH, Agarwal A, Wassick JM, Grossmann IC. "Efficient formulations for dynamic warehouse location under discrete transportation costs". Elsevier Computers\& Chemical Engineering, 111, 311-323, 2018.

[33] Kabak M, Keskin İ. "Hazardous Materials Warehouse Selection Based on GIS and MCDM". Arabian Journal for Science and Engineering, 43, 6, 3269-3278, 2018.

[34] Foroozesh N, Tavakkoli-Moghaddam R, Mousavi SM. "A novel group decision model based on mean-varianceskewness concepts and interval-valued fuzzy sets for a selection problem of the sustainable warehouse location under uncertainty". Neural Computing and Applications, 30(11), 3277-3293, 2018.

[35] Emeç Ş, Akkaya G. "Stochastic AHP and fuzzy VIKOR approach for warehouse location selection problem". Journal of Enterprise Information Management, 31(6), 950-962, 2018.

[36] Singha KR, Chaudhary N, Saxena N. "Selection of warehouse location for a global supply chain: A case study”. IIMB Management Review, 30(4), 343-356, 2018.

[37] Guo H, Pan W, Liu X, Li Y, Zeng B. “Combining a continuous location model and Heuristic techniques to determine oilfield warehouse locations under future oil well location uncertainty". Soft Computing: A Fusion of Foundations, Methodologies and Applications, 22(3), 823-837, 2018.

[38] Krylovas A, Zavadskas EK, Kosareva N, Dadelo S. "New KEMIRA method for determining criteria priority and weights in solving MCDM problem". International Journal of Information Technology \& Decision Making, 13(6), 1119-1133, 2014.

[39] Krylovas A, Kosareva N. "Gamyklos vietos parinkimo uždavinio sprendimas daugiakriteriniu KEMIRA metodu". Lietuvous Matematikos Rinkinys LMD Darbai, Series B, 56, 18-23, 2015. 
[40] Toktaş P, Can GF. "Şantiyelerin iş sağlığıve güvenliği açısından risk düzeylerine göre KEMIRA-M yöntemi ile sıralanması". Ulusal Ergonomi Kongresi, Erzurum, Türkiye, 28-30 Eylül 2018.

[41] Delice EK, Arslan N. "KEMIRA-M yöntemi ile drone seçimi". Ulusal Ergonomi Kongresi, Erzurum, Türkiye, 28-30 Eylül 2018.
[42] Toktaş P, Can GF. "AHP based KEMIRA approach for shopping mall selection". European Conf. Operational Research (EURO 2018), Valencia, Spain, 8-11 June 2018.

[43] Krylovas A, Zavadskas EK, Kosareva N, Dadelo S. "Personnel Ranking and Selection Problem Solution by Application of KEMIRA Method". International Journal of Computers Communications \& Control, 11(1), 51-66, 2016. 